\title{
DEVELOPMENT OF A GRADING MACHINE FOR OLIVES FRUITS
}

\author{
Mervat M. Atallah ${ }^{(*)}$
}

\section{ABSTRACT}

Olive trees are among the oldest known cultivated trees in the world. It is thought that the botanical progenitor of olive tree is wild tree.

The aim of this research is to development a grading machine according to the physical and mechanical properties of olive fruits.

The main results in this study can be summarized in the following points:

The maximum fruit damage of 2.8 to 3.9 and 3 to $4.1 \%$, for fruit sizes 20, $25 \mathrm{~mm}$ and total 6.7 to 9.5 and.3 to $9.8 \%$, for Azzezy and Toffahy cultivars respectively, were obtained with grading speed of $8 \mathrm{rpm}$ ( 0.08 $\mathrm{m} / \mathrm{s}$ ) and feeding rate of $20 \mathrm{~kg}$. Meanwhile, the minimum fruit-damage of 3.1 and $3.3 \%$, total 6.4 and $7.3 \%$ for Azzezy and Toffahy cultivars respectively, $20 \mathrm{~mm}$ fruit sizes was obtained with grading speed of 11 $\mathrm{rpm}(0.12 \mathrm{~m} / \mathrm{s})$, and feeding rate of $5 \mathrm{~kg}$.

The maximum range of grading-machine productivity for olive fruits of 113 - 836 and 125 - $920 \mathrm{~kg} / \mathrm{h}$ for Azzezy and Toffahy cultivars respectively, was obtained with grading speed range of 5 - 14 rpm $(0.05$ $-0.15 \mathrm{~m} / \mathrm{s}$ ) and feeding rate of $20 \mathrm{~kg}$. Meanwhile, the minimum range of grading-machine productivity for olive fruits of 101-682 and 111- 750 $\mathrm{kg} / \mathrm{h}$ for Azzezy and Toffahy cultivars was obtained with grading speed range of $5-14 \mathrm{rpm}(0.05-0.15 \mathrm{~m} / \mathrm{s})$ and feeding rate of $5 \mathrm{~kg}$.

The operation and production costs were 7.37 L.E./h and and 67, 9.7 L.E./ton for Azzezy and 62.4 , 8.9 L.E./ton for Toffahy at optimum conditions (grading speed of $11 \mathrm{rpm}$ or $0.12 \mathrm{~m} / \mathrm{s}$ and feeding rate of $10 \mathrm{~kg}$ ).

\section{INTRODUCTION}

The olive tree has a great historical importance. It played an
important role in the human live. Olive trees are considered one
of the most important crops which are grown in desert land for their superior ability to antagonize the deserts conditions like dryness, hard climate and shortage in water supply.

(*) Res., Ag. Eng. Res. Inst. Respectively. 
Also they can grow in all kinds of land, antagonize to acrimony the nature and climate. Post harvest sorting and grading of fruits is a difficult and labour intensive component of the commercial fresh fruit market.

In Egypt, there are various olive varieties which differ in their productivity, fruit maturity and quality. One of most important factors in keeping the quality of processed fruit and vegetable products is the careful grading. Grading of the raw product before processing results in greater uniformity of finished product. It also gives the consumer several grades that ranged in price according to grade standard.

Huang et al. (2000) indicated that the basic physical properties (such as, shapes, sizes and masses and rolling angles, coefficients of friction and size attribution ratio) of some fruits were investigated to provide information for the design and development of a machine suitable for post harvest processes such as picking, cleaning, grading, packing and preservation. That, the minimum angle of friction was $2 \mathrm{deg}$. $(0.03 \mathrm{rad})$ for Ruthann variety while the maximum angle was $33.5 \mathrm{deg}$. $(0.584 \mathrm{rad})$ for Sully variety.

Ismail (1988) indicated that the variation in size and shape are not only in the different crops, but also in the different varieties of the same crop. For example, the length of potato tubers averages from 35 to $90 \mathrm{~mm}$, which means that any design should make difference in shape and size. He also showed that the capacity of grading machine was $305-4.5$ $\mathrm{kg} / \mathrm{sec}$ for $1 \mathrm{~m}^{2}$ of the grading machine. The first grading unit has a 45 $\mathrm{mm}$ clearance, then the clearance, increased with a $5 \mathrm{~mm}$ interval with the other unit of the machine.

(Haydar et al 2007) mentioned that properties are necessary for the design of equipments for harvesting, processing, and transportation, separating and packing. Technological properties such as length and diameter of fruit, mass, volume of fruit, geometric mean-diameter, sphericity, bulk density, fruit density, porosity, projected area, static and dynamic coefficient of friction were determined at $83.27 \%, 77.79 \%$, $82.1 \%, 79.79 \%, 82.31 \%$ and $77.37 \%$ moisture content.

El-Raie et al. (1998) designed and fabricated grading machine for orange using diverging bar and roller cylinder. The results showed that, the optimum speed of feeding conveyor was $70 \mathrm{rpm}$., the most suitable 
lines for the grading unit were the cylinders system, and the most suitable tilt angle of grading unit ranged between 0.052-0.105 rad. (3-6 degree) which gave 4.2 ton/h, grading efficiencies of 56 and $44 \%$ for two sizes.

Mousa (1998) found that the mean values of diameter ranged from about 28.1 to 41.4; and height ranged from about 26.7 to $40 \mathrm{~mm}$; mass ranged from about 15 to $35 \mathrm{~g}$; volume ranged from 17 to $40 \mathrm{~mm}^{3}$ for Egyptian lime. The height values limited the distance between grading lines and shape and size of the distributed buckets on the conveyor belt. According to that, the grading-pipes design was: the distances between two pipes for grading lime are 20 and $50 \mathrm{~mm}$ at the beginning and ending of grading line.

Matouk et al. (1999) designed and constructed a portable machine for sorting, cleaning and grading sphere-like crops such as orange and tomatoes. They concluded that, at any sieve slope the range of 0.87-0.349 rad. (5-0 deg) and all sieve king speed in the range of 150-300 rpm mechanical damage percentage of fruits increased as the speed of fruits feeding chain increased from $0.15-0.3 \mathrm{~m} / \mathrm{s}$. They added that at high sieve rocking speed the grading efficiency of fruit decreased.

Radwan (2000) reported that, the grading efficiency decreased with increasing both fruit feeding speed and tilt angle of grading unit. However, the grading efficiency increased with the increase of critical distance from 0.04 to $0.1 \mathrm{~m}$ and starts to decrease at critical distance of $0.13 \mathrm{~m}$.

Shabana (2002) developed and evaluated grading machine which consisted of rotating screen cylinder for orange variety. He found that the optimum operational condition for obtaining the maximum grading efficiency of each variety was as follows:

For navle orange variety, a maximum grading efficiency of $93.3 \%$ was obtained at $0.18 \mathrm{~m} / \mathrm{s}$ feeding speed, $0.16 \mathrm{rad}$ ( 9 deg.) tilt angle and 0.314 $\mathrm{m} / \mathrm{s}$ (20 r.p.m.) screen speed.

Abd-Alla et al. (2000) reported that:

1- The grading efficiency decreased with increasing both fruit feeding speed and tilt angle of grading unit.

2- The grading efficiency increased with the increase of critical distance from 0.04 to $0.1 \mathrm{~m}$ and starts to decrease at critical distance of $0.13 \mathrm{~m}$. 
3- The mass-grading machine consumes an average power of $0.0084 \mathrm{~kW}$ for potato varieties and $0.001 \mathrm{~kW}$ for orange variety.

4- The total cost of grading one ton of potato variety was 13.15 L.E. in comparison with 9.05 L.E. for orange.

There are two specific objectives of this study:

1- Study the physical and mechanical properties of olive fruits "Toffahy and Azzezy" are data base to help for the design grading machine.

2- Develop of the grading machine (Design the grading- three revolving drums ) as a case study.

\section{MATERIAL AND METHODS}

\subsection{Fruits.}

Olive crop "Toffahy and Azzezy" varieties was considered in this study. All measurements were done using a random sample of 100 fruits. The samples were taken randomly from olive trees (private farm) and from "El Oboor" Market; and the measurements were taken in the same day.

\subsection{Grading-machine.}

The grading machine for olive fruits consists of the following parts (Fig. 1) and (Fig. 2), shows a schematic diagram of the development gradingmachine. Parameters shown on the figure are essentially those to be determined for olive through this work, for modifying the grading machine to operate efficiently on this fruit. (designed by El-Raie et al, 2012)

\subsubsection{Designed grading- three revolving drums}

Designed Grading revolving-drums: Three revolving drums are made of PVC with diameter of $200 \mathrm{~mm}$ and length of $430 \mathrm{~mm}$. Thickness of 4 $\mathrm{mm}$ and spacing $6 \mathrm{~mm}$ (fig. 3a). The three grading-drums have hole diameters of 20, 25 and $30 \mathrm{~mm}$ and number of holes are 156, 137 and 124, respectively. Iron metal-sheet of $35 \mathrm{~mm}$ length, $32 \mathrm{~mm}$ width and $1.5 \mathrm{~mm}$ thickness was assembled above grading-drums spacing and bolted on two sides of fruit boxes.

2.2.1.1. Fruit out put unit : made PVC sheet with length of $450 \mathrm{~mm}$ and width of $160 \mathrm{~mm}$ (fig. 3b). Three fruit cutoffs were passed inside the three grading drums and were hinged with left side of frame by cantilevers. The fruits roll on the concaved part of out put unit and drop into funnels. The curved part prevents the jamming of fruits. The total inclined-angle of out put unit is $11.5^{\circ}$.

2.2.2. Transmittion system and motor: consist of motor of $0.3 \mathrm{hp}(225$ $\mathrm{kW}$ ) and chains and sprockets as shown in fig. 4. 

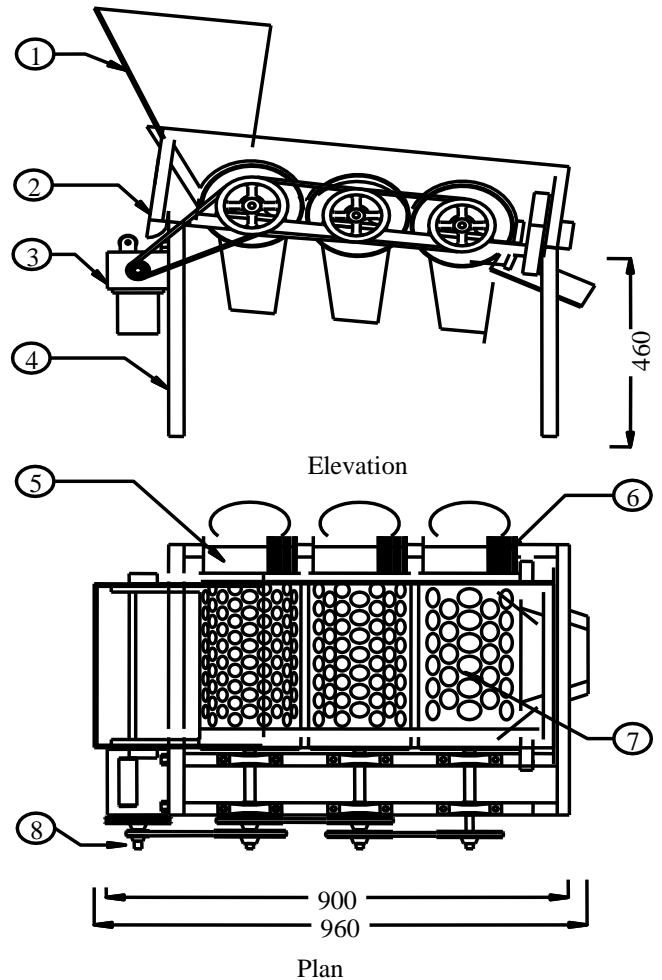

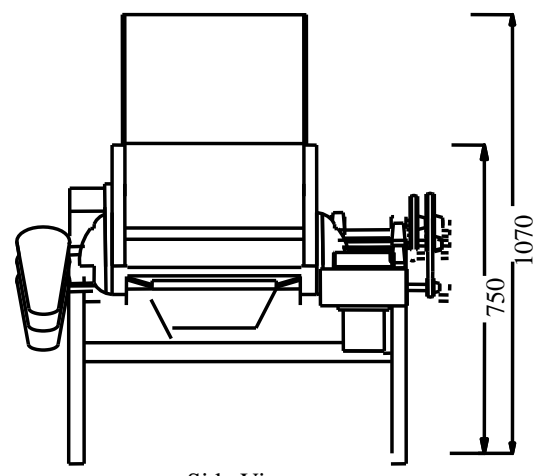

Side View Dim. in mm.

1- Fruit hopper (box).

2- Frame.

3- Motor.

4- Stand.

5- Chute.

6- Cutoff.

7- Revolving drum.

8- Transmutation system.

Dims. in mm.

Fig. 1: Views of designed grading-machine for olive fruits.

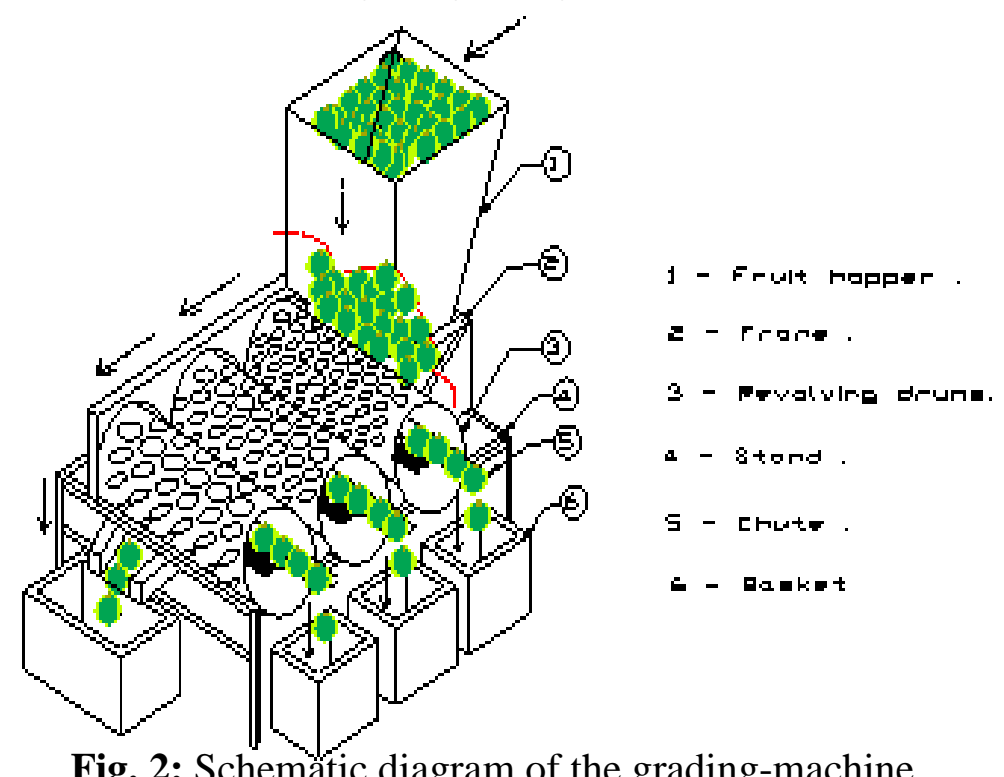

Fig. 2: Schemâtic diagram of the grading-machine. 

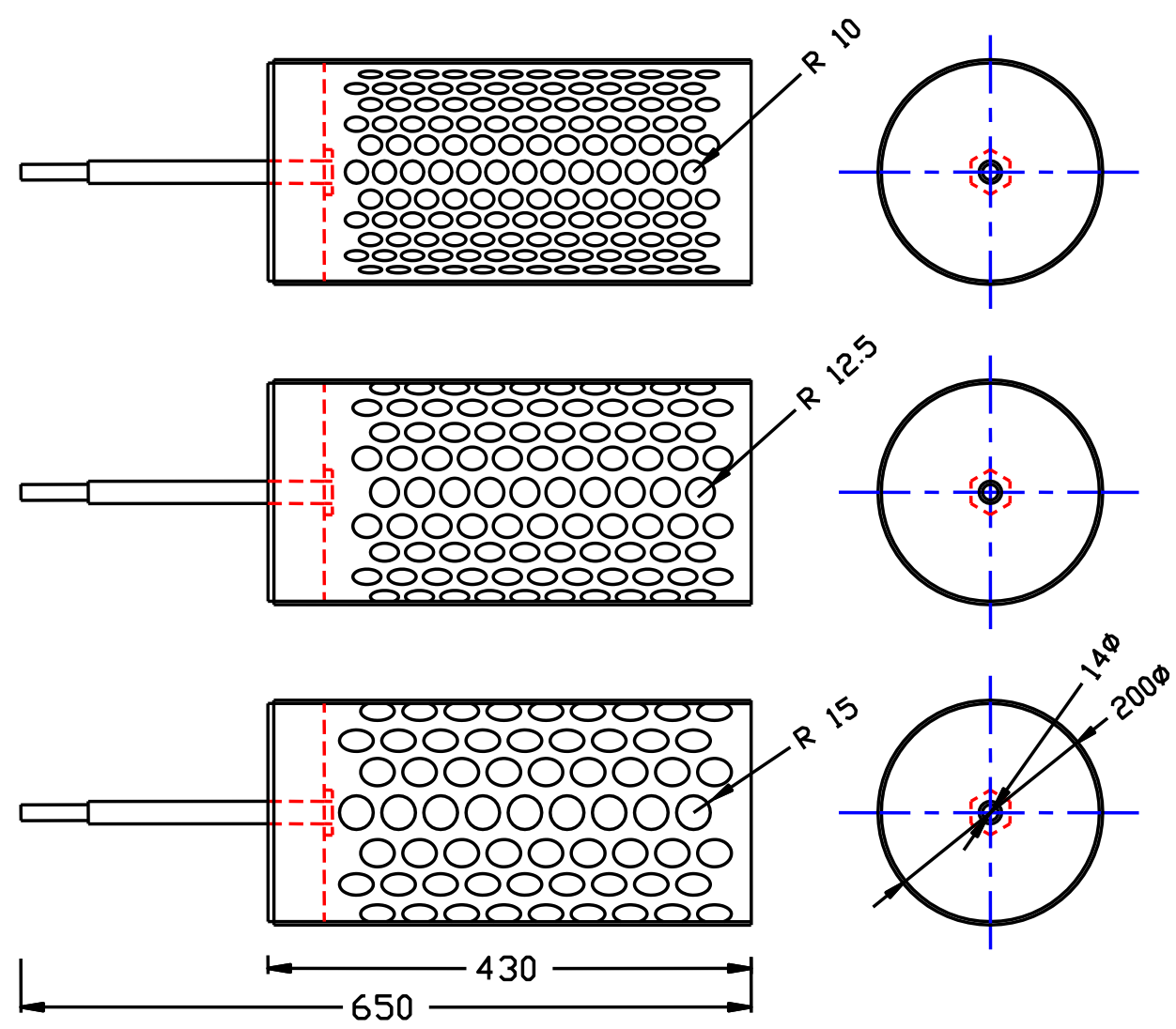

(a) Grading revolving-drums.

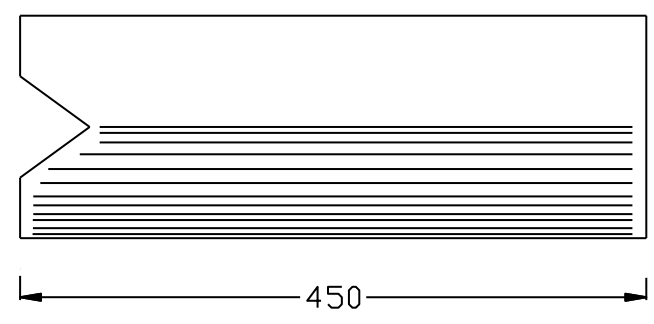

(b) Fruit out put unit. Dims. in mm.

Fig. 3: Views of grading revolving-drums and fruit out put unit 

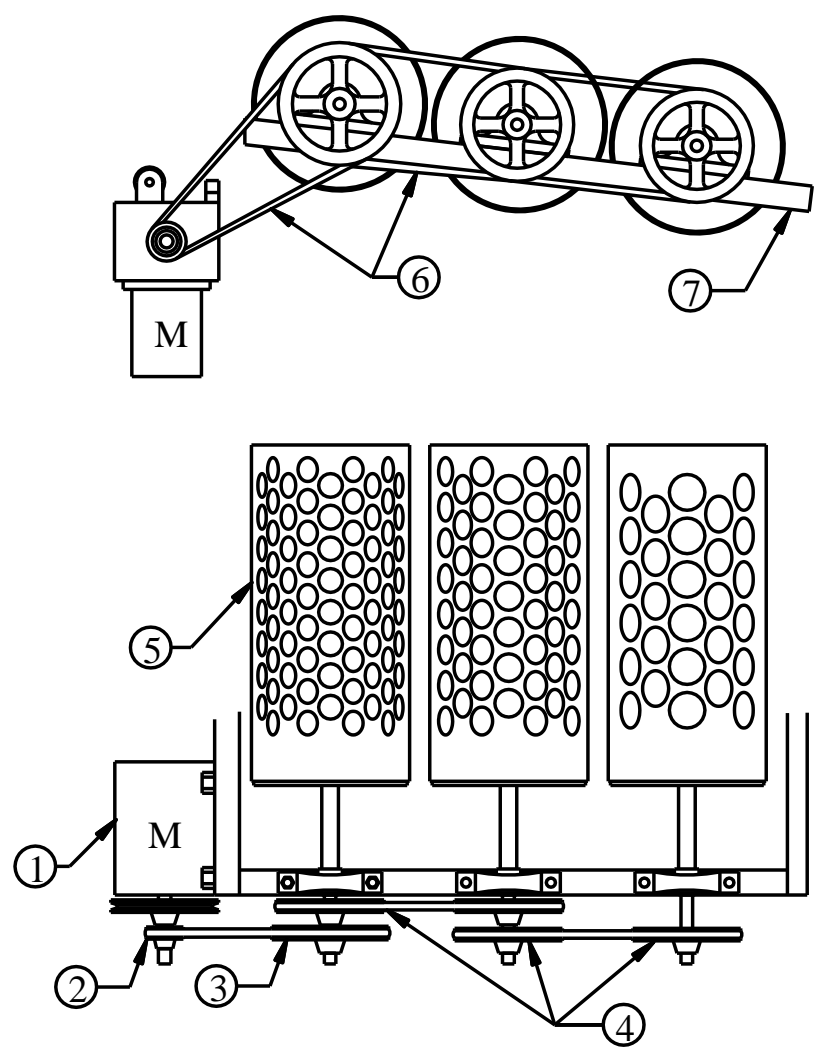

1- Motor.

2- Pulley Dim. 5mm.

3- Pulley Dim. $130 \mathrm{~mm}$.

4- 4 Pulleys Dim. 120 mm.

5- Grading revolving-drum.

6- Belt.

7- Frame.

Fig. 4: Views of grading transmittion system of grading machine.

\subsection{Development steps and specifications of components of the grading machine:}

The physical and mechanical properties are incorporated in the development of the fruit hopper, revolving drums with holes (length and diameters of drums, diameter of holes, and number of holes) and exit chute of the development grading-machine as follows:

\subsubsection{Fruit hopper :}

Hopper dimensions: to suit feeding rate and bulk density of fruits are top dimensions of $350 \times 330 \mathrm{~mm}$ and bottom dimensions of $350 \times 80 \mathrm{~mm}$. Fruit hopper side-slope more than maximum $30^{\circ}$ friction angle of olive fruits with wood surface $=60^{\circ}$.

\subsubsection{Grading drums:}

Revolving drums with holes are used to grade the fruits to 3 sizes: 
Drum hole diameters are must be more than fruit diameters the olive fruits cultivars

Drum hole diameters are 20, 25, and $30 \mathrm{~mm}$. The fruit $>30 \mathrm{~mm}$ exit from the end of the machine.

No. of drums to suit No. of olive categories are 3.

Rotating drums with holes diameter and length to suit machine productivity $=$ about $20 \mathrm{~cm}$ diameter and $100 \mathrm{~cm}$ length .

Drums tangential angle at fruit exit direction must be more than $17^{0}$ rolling angle between olive fruits and PVC surface .

Drums tangential angle at drum-motion direction (found experimentally) are $7^{0}$.

\subsubsection{Fruit out put unit :}

Drums tangential angle should be more than $17^{0}$ rolling angle between olive fruits and PVC surface.

\section{Instrumentation:}

Digital caliper with vernier: with accuracy of $0.01 \mathrm{~mm}$, to measure different dimensions of olive fruits.

Digital balance: with accuracy of $0.2 \mathrm{~g}$, to measure mass of the olive fruits .

Graduated cylinder: of $1000 \mathrm{~mL}$ with accuracy of $25 \mathrm{~mL}$ to determine the real density and volume of fruit by immersion in water.

Friction and rolling-angle measuring device: an inclined plane was used to measure friction and rolling angles.

Friction angle measurement: the fruits are placed as a group bounded together on a horizontal surface then the angle of inclination is gradually increased until the fruits begin sliding without rolling. For each fruits group of an average sample of (10), the friction angles were determined.

Rolling angle measurement: the fruits are placed on a horizontal surface one by one then the angle of inclination is gradually increased until the fruits begin roll. For each fruit of an average sample (50), two angles of rolling are determined: for the maximum stable (with their base down) and minimum stable positions. 
Penetrometer: Penetrometer, made in Italy, with accuracy of $0.1 \mathrm{~N}$ was used to measure penetration force of olive fruits. The firmness of fruit was obtained by dividing the penetration force by the area $\left(0.28 \mathrm{~cm}^{2}\right)$ of cylindrical probe, which had $0.6 \mathrm{~cm}$ diameter.

\section{Studied factors and measurements:}

The studied factors of development grading-machine were:

(1) Grading speed: Four different grading speeds 5, 8, 11 and $14 \mathrm{rpm}$ $(0.05,0.08,0.12$ and $0.15 \mathrm{~m} / \mathrm{s})$.

(2) Feeding rate : Four different feed rates of 5, 10, 15 and $20 \mathrm{~kg}$.

The measurements were: (1) grading efficiency, (2) fruit damage and (3) grading productivity.

\section{Equations and calculations:}

The following equations were used to calculate sphericity, projected area and real density according to Mohsenin, 1986.

Sphericity ratio $=$ fruit height $(\mathrm{H}) /$ fruit diameter $(\mathrm{D})$

Projected area $=4 / \pi(D * H)$

Real density $=$ Mass $/$ Volume

Grading productivity: Was calculated by using the following formula according to Amin (1994):

$$
\mathbf{P}=\frac{3600 * M}{T}
$$

Where: $\mathrm{P}=$ Grading productivity, $\mathrm{kg} / \mathrm{h}$.

$$
\begin{aligned}
\mathrm{M} & =\text { Mass of sample, } \mathrm{kg} \text { and } \\
\mathrm{T} & =\text { Time in seconds. }
\end{aligned}
$$

Grading efficiency: The grading efficiency $(\boldsymbol{\mu})$ of each outlet has been calculated according to Amin (1994) as follows :

$\mu_{1}=M_{01} / M_{i 1}, \mu_{2}=M_{01} / M_{i 1}, \mu_{3}=M_{01} / M_{i 1}$, and $\mu_{4}=M_{01} / M_{i 1}$

Where: $\mu_{1}, \mu_{2}, \mu_{3}$ and $\mu_{4}$ : Grading efficiency of fruits for each outlet in the machine, $\%$.

$\mathbf{M}_{\mathbf{i 1}}, \mathbf{M}_{\mathbf{i} 2}, \mathbf{M}_{\mathbf{i 3}}$ and $\mathbf{M}_{\mathbf{i} 4}$ : Mass of each class inside fruit hopper, $\mathrm{kg}$ and 
$\mathbf{M}_{\mathbf{0 1}}, \mathbf{M}_{\mathbf{0 2}}, \mathbf{M}_{\mathbf{0 3}}$ and $\mathbf{M}_{\mathbf{0 4}}$ : Mass of the fruit for each outlet in the machine, $\mathrm{kg}$.

Total grading efficiency: The total grading efficiency machine $(\boldsymbol{\mu})$ has been calculated using the following equation:

$$
\mu=\left(\mu_{1}+\mu_{2}+\mu_{3}+\mu_{4}\right) / 4
$$

Mechanical damage (Df) : Percentage of mechanical damage was calculated by using the following formula:

$$
\mathbf{D f}=\frac{N d}{N t} x 100
$$

Where: $\mathrm{N}_{\mathrm{d}}=$ Number of damaged fruits and

$\mathrm{N}_{\mathrm{t}}=$ Total number of fruits.

Estimating the costs of using the machine: The operation cost of machine was calculated according to the following equation given by Awady, 1978 (updating 1998) modified for electrical motor drive:

$$
C=P / h(1 / a+I / 2+t+r)+(w . e)+m / 144
$$

Where: $\mathrm{C}=$ hourly cost, $\mathrm{P}=$ price of machine, $\mathrm{h}=$ yearly working-hours, $\mathrm{a}=$ life expectancy of machine, $\mathrm{I}=$ interest rate/year, $\mathrm{t}=$ taxes and overhead ratio, $\mathrm{w}=$ power of motor in $\mathrm{kW}, \mathrm{e}=$ hourly $\operatorname{cost} / \mathrm{kW} . \mathrm{h}$, and $\mathrm{m} / 144=$ monthly wage ratio per hour.

Notice that all units have to be consistent to result in " $\mathrm{C}=\mathrm{LE} / \mathrm{h}$ ".

Operating cost $(\mathrm{L} . \mathrm{E} . / \mathrm{ton})=$ machine cost $(\mathrm{LE} / \mathrm{h}) /$ machine productivity (ton/h)

\section{RESULTS AND DISCUSSION}

\subsection{Physical properties of olive fruits.}

Table 1 shows dimensions, sphericity, mass, volume, real density and projected area, olive fruits. These data were measured on 100 fruit sample, according to the standards set in (Mohsenin, 1986).

\subsubsection{Dimensions of fruit:}

Fig. 5 indicates that the fruit diameter and height ranges of sample were 17 - $29 \mathrm{~mm}$ (average $25 \mathrm{~mm}$ ) and $20-35 \mathrm{~mm}$ (average $30 \mathrm{~mm}$ ), respectively, for Azzezy cultivar and 19.5-31.9 mm (average $26.3 \mathrm{~mm}$ ) 
and 22.8 - $36.5 \mathrm{~mm}$ (average $29.6 \mathrm{~mm}$ ), respectively, for Toffahy cultivar. The most frequent percent $(85 \%)$ of olive fruits in the sample have $20-30 \mathrm{~mm}$ diameter and (95\%) f or olive fruits in the sample have 20 - $35 \mathrm{~mm}$ height.

\subsubsection{Shape and size of fruit:}

If sphericity is less than 0.9 , the fruit belongs to oblate group; if sphericity is greater than 1.1, it belongs to oblong group. The remaining fruits with intermediate index values are considered to be round (Buyanov and Voronyuk, 1985).

Fig. 5 indicates that the fruit sphericity ranged in sample between 1.03 and 1.38 for Azzezy cultivar, the most frequent percent (100\%) of olive fruits in the sample was a round (sphericity $0.8-1.1$ ). and the fruit sphericity ranges in sample were 0.83 and 1.2 for Toffahy cultivar. The most frequent percent $(85 \%)$ of olive fruits in the sample was a round (sphericity $0.9-1.1)$ and $(15 \%)$ for olive fruits in the sample were oblong (sphericity $1.1-1.4$ ).

Table (1) : Main dimensions and some properties of the olive two caltivars : Azzezy and Toffahy.

\begin{tabular}{|c|c|c|c|c|c|c|c|}
\hline \multicolumn{2}{|c|}{ Cultivars } & Physical properties & Max. & Min. & Average & S. D. (1) & C. V. (2) \\
\hline \multirow{16}{*}{ Cultivars } & \multirow{8}{*}{ Azzezy } & Height, mm & 35 & 20 & 30 & 4.0 & 13.7 \\
\hline & & Diameter, mm & 29 & 17 & 25 & 2.8 & 11.4 \\
\hline & & Projected area,cm2 & 12.7 & 4.57 & 9.34 & 2.13 & 22.84 \\
\hline & & Sphericity & 1.38 & 1.03 & 1.20 & 0.08 & 6.75 \\
\hline & & Mass, $\mathrm{g}$ & 19 & 5 & 10.8 & 3.49 & 32.25 \\
\hline & & Volume, cm3 & 20.9 & 4.55 & 10.94 & 3.99 & 36.45 \\
\hline & & Bulk density, g/cm3 & \multicolumn{5}{|c|}{0.64} \\
\hline & & Real density, g/cm3 & 1.10 & 0.91 & 1.06 & 0.10 & 9.65 \\
\hline & \multirow{8}{*}{ Toffahy } & Height, mm & 36.5 & 22.8 & 29.6 & 2.9 & 9.8 \\
\hline & & Diameter, mm & 31.9 & 19.5 & 26.3 & 2.4 & 9.1 \\
\hline & & Projected area,cm2 & 13.9 & 5.67 & 9.96 & 1.68 & 16.88 \\
\hline & & Sphericity & 1.2 & 0.83 & 1.13 & 0.08 & 7.09 \\
\hline & & Mass, $\mathrm{g}$ & 18 & 6 & 12.05 & 2.78 & 23.09 \\
\hline & & Volume, cm3 & 18.7 & 6.6 & 13.09 & 3.49 & 26.70 \\
\hline & & Bulk density, g/cm3 & \multicolumn{5}{|c|}{0.63} \\
\hline & & Real density, g/cm3 & 1.7 & 0.8 & 1.1 & 0.2 & 23.5 \\
\hline
\end{tabular}

(1) S. D. is standard deviation.

(2) C. V. is coefficient of variation. 


\subsubsection{Mass and volume of fruit:}

Fig. 5 indicates that the fruit mass and volume ranges of sample were 5 $15 \mathrm{~g}$ (average $10.8 \mathrm{~g}$ ) and $4.55-20.9 \mathrm{~cm}^{3}$ (average $10.94 \mathrm{~cm}^{3}$ ) respectively, for Azzezy cultivar, and the fruit mass and volume ranges of sample were $6-18 \mathrm{~g}$ (average $12.05 \mathrm{~g}$ ) and $6.6-18.7 \mathrm{~cm}^{3}$ (average $13.09 \mathrm{~cm}^{3}$ ) respectively, for Toffahy cultivar. The most frequent percent $(70 \%)$ of olive fruits in the sample had $6-15 \mathrm{~g}$ mass and (80\%) had 6 $18 \mathrm{~cm}^{3}$ volume.

\subsection{Mechanical properties of olive fruits.}

\subsubsection{Friction, rolling and repose angles of olive fruits:}

Table 2 shows friction and rolling angles of olive fruits. The maximum friction angle (26 - 30 degree) and rolling angle ranges (21 - 38 degree) were obtained with wood surface. Whereas, the minimum range of friction angle of 7 - 15 was obtained with PVC surface and minimum rolling angle of $8-18$ was obtained with aluminium surface.

\subsection{Effect of grading speed and fruit batch on grading efficiency:}

Fig. 6 shows the effect of grading speed and fruit batch on grading efficiency of four fruit-sizes.

The maximum grading efficiencies of 93.29, 95.97, 97.13, $100 \%$ total 96.6 \% for Azzezy cultivar, and 99.37, 99.67, 99.93 and $100 \%$ total $99.97 \%$ for Toffahy cultivar, for fruit sizes $20,25,30,>30 \mathrm{~mm}$ respectively, were obtained with grading speed of $11 \mathrm{rpm}(0.12 \mathrm{~m} / \mathrm{s})$ and feeding rate of $5 \mathrm{~kg}$. Meanwhile, the minimum grading efficiencies of 81.32, 83.35, 89.77 and $100 \%$ total $88.56 \%$, for Azzezy cultivar, 81.52, $83.6,90$ and $99.5 \%$ total $88.78 \%$ for

Table 2: Friction and rolling angles for olive fruits with different surface types for Azzezy and Toffahy cultivars.

\begin{tabular}{|c|c|c|c|c|c|c|c|c|c|}
\hline \multirow{2}{*}{$\begin{array}{c}\text { Surface } \\
\text { type }\end{array}$} & \multicolumn{3}{|c|}{$\begin{array}{c}\text { Friction angle, } \\
\text { degree }\end{array}$} & \multicolumn{5}{c|}{ Rolling angle, degree } \\
\cline { 2 - 10 } & Max. & Min. & Av. & Max. & Min. & Av. & Max. & Min. & Av. \\
\hline Wood & 30 & 26 & 25.6 & 38 & 21 & 30 & 23 & 12 & 17.5 \\
\hline Metal & 12 & 10 & 11.1 & 22 & 16 & 19 & 10 & 8 & 9.0 \\
\hline Galv. I. & 12 & 10 & 11.1 & 17 & 16 & 17 & 11 & 8 & 9.5 \\
\hline Alum. & 12 & 10 & 10.8 & 17 & 15 & 16 & 11 & 7 & 9.0 \\
\hline SS & 12 & 10 & 11.1 & 17 & 16 & 17 & 10 & 8 & 9.0 \\
\hline PVC & 11 & 10 & 10.4 & 17 & 18 & 18 & 10 & 8 & 9.0 \\
\hline
\end{tabular}

Galv. I.: Galvanized iron; Alum.: Aluminium; and SS.: Stainless steal. The average repose-angle was about 35.5 degree. 
Toffahy cultivar, for fruit sizes $20,25,30,>30 \mathrm{~mm}$, respectively, were obtained with grading speed of $14 \mathrm{rpm}(0.15 \mathrm{~m} / \mathrm{s})$ and feeding rate of 20 $\mathrm{kg}$. The decreasing of grading efficiency by increasing grading speed and feeding rate is due to decreasing the time of grading and accumulating of fruits on drum holes, respectively.

\subsection{Effect of grading speed and fruit batch on fruit damage:}

Table 3 (A,B) shows the effect of grading speed and fruit batch on fruit damage of four fruit-sizes. The fruit damage was increased by increasing grading speed and feeding rate. The maximum fruit damage increased from 2.8 to $3.9 \%$ as the grading speed increased from 5 to $14 \mathrm{rpm}$ at fruit feeding rate of $20 \mathrm{~kg}$, total 6.7 to $9.5 \%$, for Azzezy cultivar, and the maximum fruit damage increased from 3 to $4.1 \%$ as the grading speed increased from 5 to $14 \mathrm{rpm}$ at feeding rate of $20 \mathrm{~kg}$, total 7.3 to $9.8 \%$, for Toffahy cultivar, for fruit sizes $20,25 \mathrm{~mm}$. Meanwhile, the minimum fruit-damage of 3.1 and $3.3 \%$, total 6.4 and $7.3 \%$ for Azzezy and Toffahy cultivars respectively, $20 \mathrm{~mm}$ fruit sizes was obtained with grading speed of $11 \mathrm{rpm}(0.12 \mathrm{~m} / \mathrm{s})$, and feeding rate of $5 \mathrm{~kg}$. The caused fruit-damage by using grading speed of 5 and $11 \mathrm{rpm}(0.05$ and $0.12 \mathrm{~m} / \mathrm{s})$ is due to fruit jamming between fruit cutoff and grading drum.

\subsection{Effect of grading speed and fruit batch on machine productivity:}

Fig. 7 shows the effect of grading speed and fruit batch on gradingmachine productivity. The maximum range of grading-machine productivity for olive fruits of $113-836$ and $125-920 \mathrm{~kg} / \mathrm{h}$ for Azzezy and Toffahy cultivars respectively, was obtained with grading speed range of $5-14 \mathrm{rpm}(0.05-0.15 \mathrm{~m} / \mathrm{s})$ and feeding rate of $20 \mathrm{~kg}$. Meanwhile, the minimum range of grading-machine productivity for olive fruits of $101-682$ and $111-750 \mathrm{~kg} / \mathrm{h}$ for Azzezy and Toffahy cultivars was obtained with grading speed range of 5 - $14 \mathrm{rpm}(0.05-$ $0.15 \mathrm{~m} / \mathrm{s}$ ) and fruit feeding rate of $5 \mathrm{~kg}$. The increasing of gradingmachine productivity by increasing grading speed and feeding rate is due to decreasing the time of grading and fruit mass, respectively. 

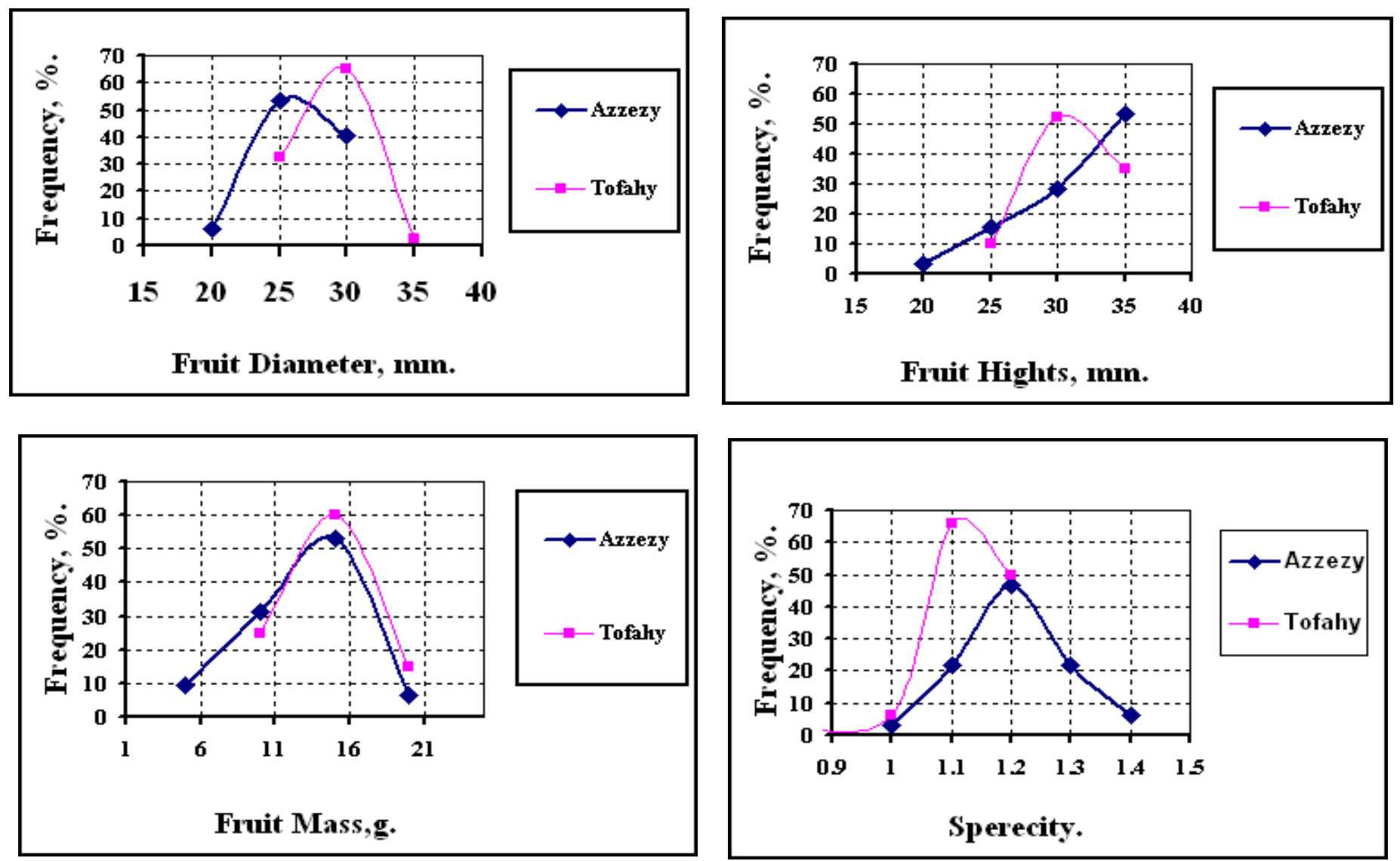

Fig. 5 : Frequency curves distribution of fruit dimensions (diameter, height and mass ) and sphericity of olive fruits. 


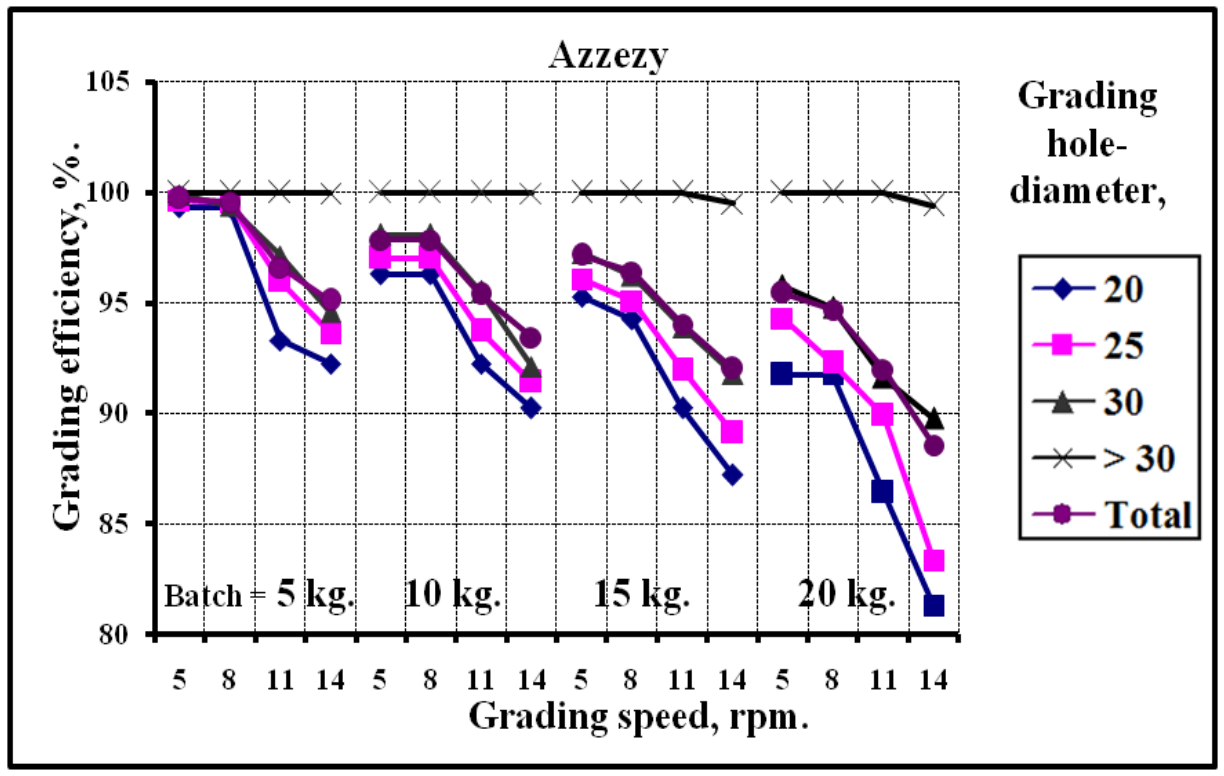

\section{(A}

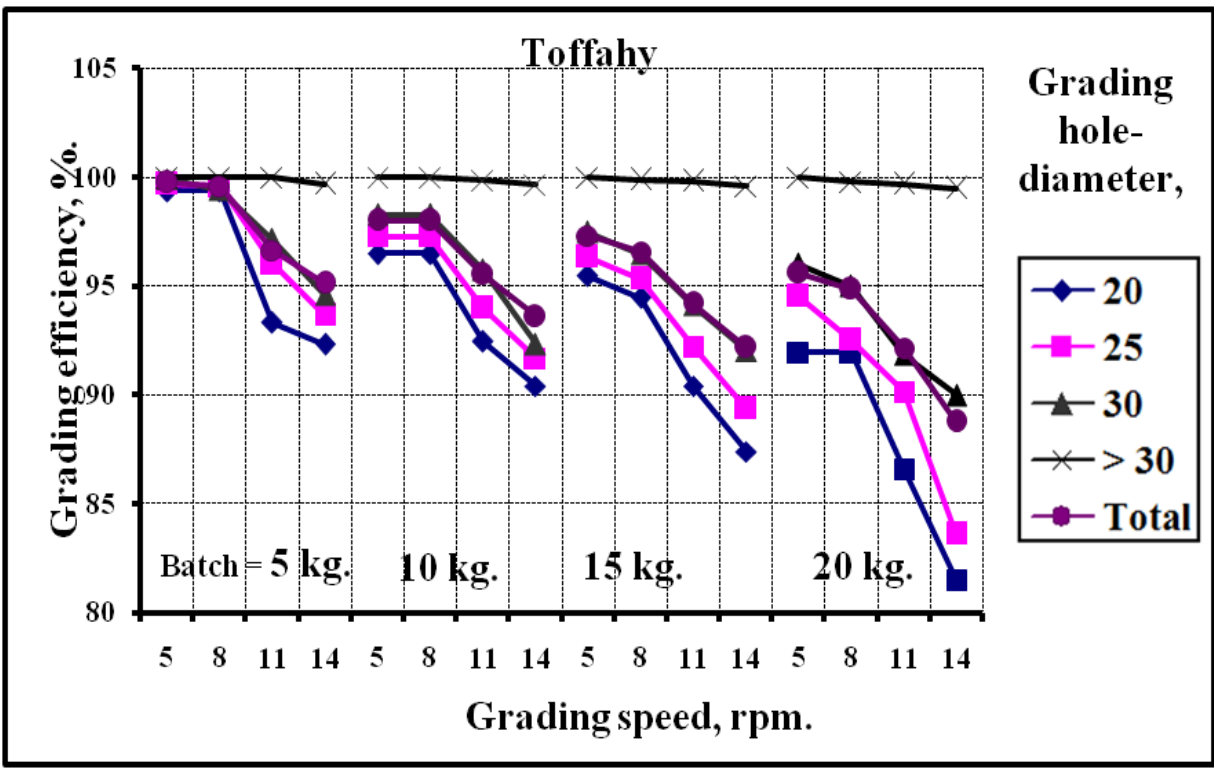

\section{(B}

Fig. 6 : Effect of grading speed, hole diameter of grading drums and fruit batch on machine grading efficiency. 
Table 3-A: Effect of grading speed, feeding rate-mass and fruit size on fruit damage for Azzezy olive cultivar.

\begin{tabular}{|c|c|c|c|c|c|c|}
\hline \multirow{3}{*}{$\begin{array}{c}\text { Feeding } \\
\text { rate, } \\
\text { kg }\end{array}$} & \multirow{3}{*}{$\begin{array}{l}\text { Grading } \\
\text { speed, } \\
\text { rpm. }\end{array}$} & \multicolumn{5}{|c|}{ Fruit damage, $\%$. } \\
\hline & & \multicolumn{5}{|c|}{ Fruit diameter, mm. } \\
\hline & & 20 & 25 & 30 & $>30$ & Total \\
\hline \multirow[t]{4}{*}{5} & 5 & 1.9 & 2 & 0.3 & 0 & 4.4 \\
\hline & 8 & 2.2 & 2.9 & 0.6 & 0 & 5.7 \\
\hline & 11 & 3.1 & 3.3 & 0 & 0 & 6.4 \\
\hline & 14 & 3.2 & 3.5 & 0.8 & 0.1 & 7.6 \\
\hline \multirow[t]{4}{*}{10} & 5 & 2.2 & 2.6 & 0.4 & 0 & 5.2 \\
\hline & 8 & 3.2 & 3.7 & 0.5 & 0 & 7.6 \\
\hline & 11 & 3.4 & 3.4 & 0.7 & 0 & 7.7 \\
\hline & 14 & 3.5 & 3.6 & 0.9 & 0.12 & 8.6 \\
\hline \multirow[t]{4}{*}{15} & 5 & 2.7 & 2.8 & 0.5 & 0 & 6 \\
\hline & 8 & 3.6 & 3.7 & 0.7 & 0 & 8 \\
\hline & 11 & 3.7 & 3.8 & 0.8 & 0 & 8.5 \\
\hline & 14 & 3.75 & 3.8 & 1 & 0.15 & 8.75 \\
\hline \multirow[t]{4}{*}{20} & 5 & 2.8 & 2.9 & 0.7 & 0 & 6.7 \\
\hline & 8 & 3.5 & 3.95 & 0.8 & 0 & 8.45 \\
\hline & 11 & 3.6 & 4 & 0.8 & 0 & 8.7 \\
\hline & 14 & 3.9 & 4.1 & 0.9 & 0.2 & 9.5 \\
\hline
\end{tabular}

Table 3-B: Effect of grading speed, feeding rate-mass and fruit size on fruit damage for Toffahy olive cultivar.

\begin{tabular}{|c|c|c|c|c|c|c|}
\hline \multirow{3}{*}{$\begin{array}{c}\text { Feeding } \\
\text { rate, } \\
\text { kg } \\
\end{array}$} & \multirow{3}{*}{$\begin{array}{c}\text { Grading } \\
\text { speed, } \\
\text { rpm. }\end{array}$} & \multicolumn{5}{|c|}{ Fruit damage, $\%$. } \\
\hline & & \multicolumn{5}{|c|}{ Fruit diameter, mm. } \\
\hline & & 20 & 25 & 30 & $>\mathbf{3 0}$ & Total \\
\hline \multirow[t]{4}{*}{5} & 5 & 2.1 & 2.3 & 0.7 & 0 & 5.1 \\
\hline & 8 & 2.6 & 3.0 & 1 & 0 & 6.6 \\
\hline & 11 & 3.3 & 3.6 & 0.4 & 0 & 7.3 \\
\hline & 14 & 3.4 & 3.8 & 1.2 & 0.12 & 8.5 \\
\hline \multirow[t]{4}{*}{10} & 5 & 2.4 & 2.9 & 0.8 & 0 & 6.1 \\
\hline & 8 & 3.4 & 4 & 0.9 & 0 & 8.3 \\
\hline & 11 & 3.6 & 3.7 & 1.1 & 0 & 8.4 \\
\hline & 14 & 3.7 & 3.9 & 1.3 & 0.14 & 9.0 \\
\hline \multirow[t]{4}{*}{15} & 5 & 2.9 & 3.1 & 0.9 & 0 & 6.9 \\
\hline & 8 & 3.8 & 4 & 1.1 & 0 & 8.9 \\
\hline & 11 & 3.9 & 4.1 & 1.2 & 0 & 9.2 \\
\hline & 14 & 3.95 & 4.1 & 1.4 & 0.17 & 9.6 \\
\hline \multirow[t]{4}{*}{20} & 5 & 3 & 3.2 & 1.1 & 0 & 7.3 \\
\hline & 8 & 3.7 & 4.25 & 1.2 & 0 & 9.2 \\
\hline & 11 & 3.8 & 4.3 & 1.2 & 0 & 9.3 \\
\hline & 14 & 4.1 & 4.3 & 1.2 & 0.22 & 9.8 \\
\hline
\end{tabular}




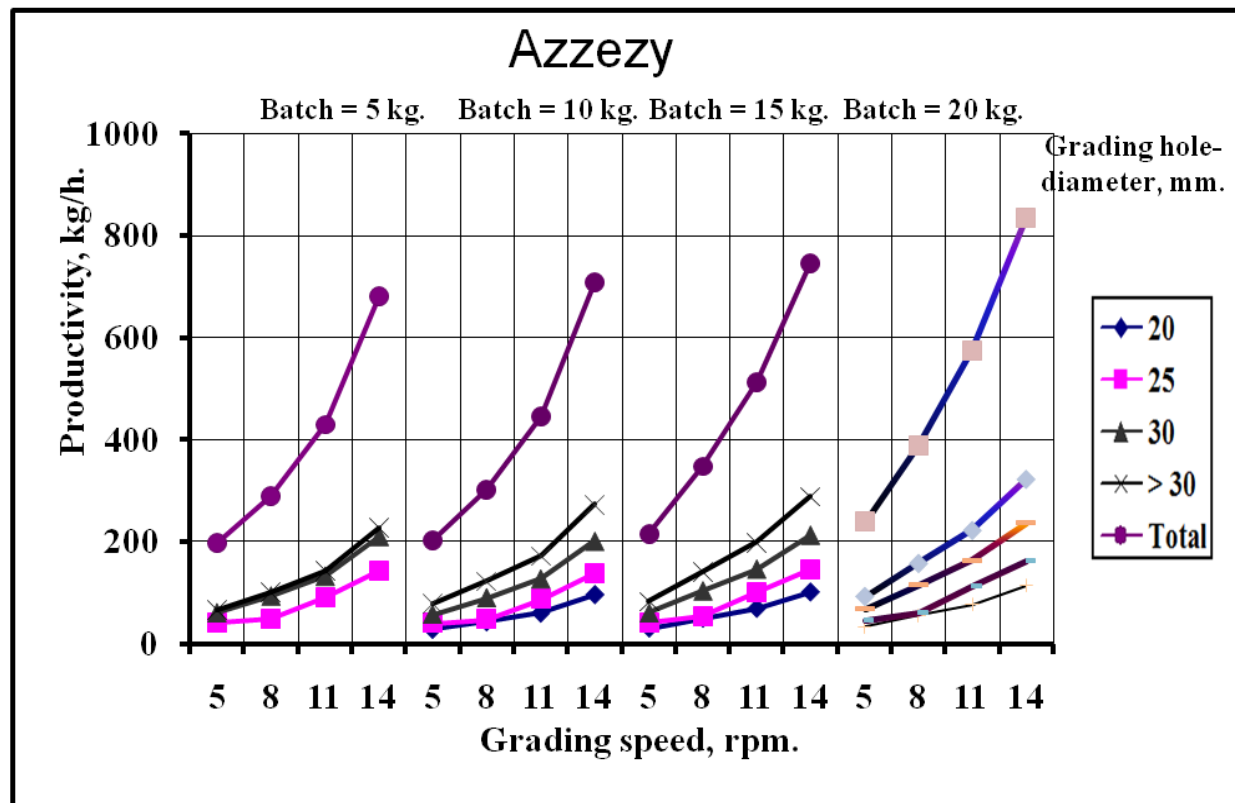

A

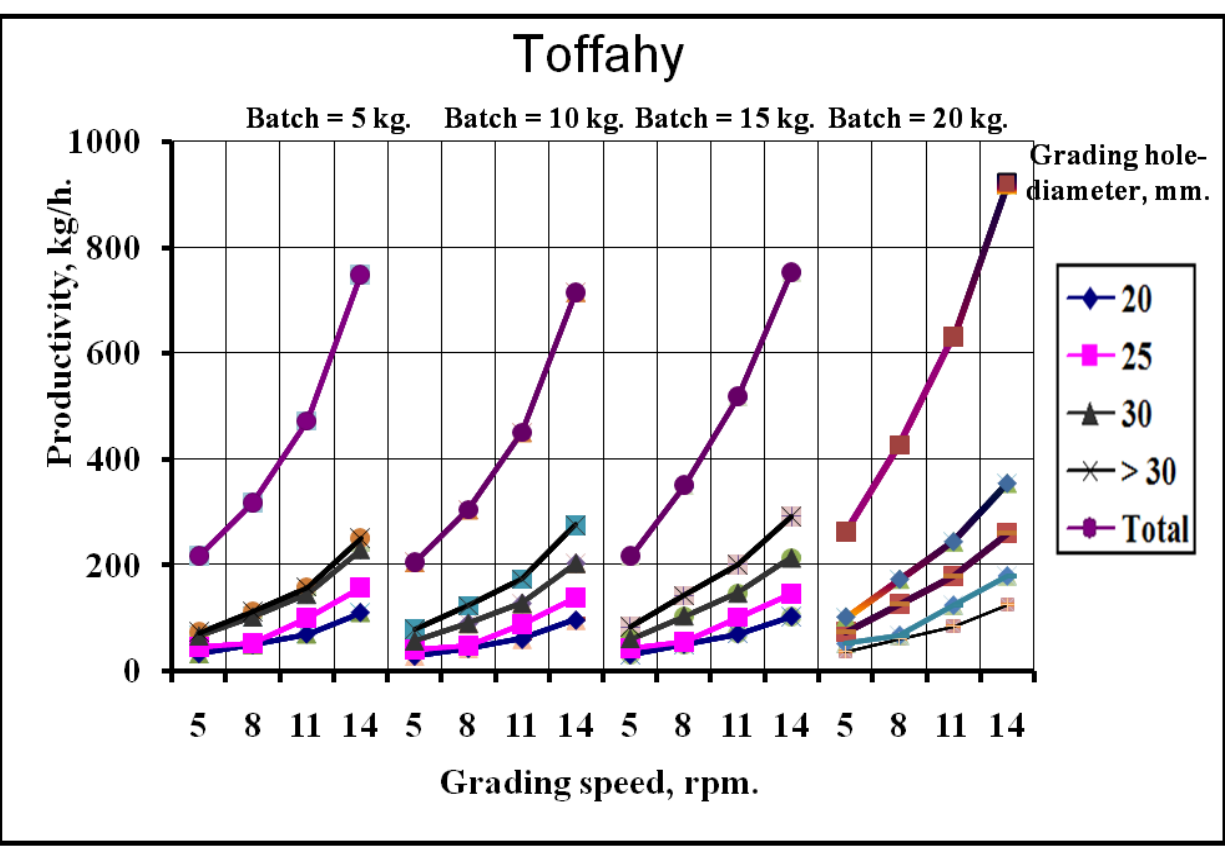

\section{B}

Fig. 7 : Effect of grading speed, hole diameter of grading drums and feeding rate on machine grading productivity. 


\subsection{Cost of using the designed grading-machine:}

Table 4 shows the components of the Awady equation.

The operation and production costs were 7.37 L.E./h and 67, 9.7 L.E./ton for Azzezy and $62.4,8.9$ L.E./ton for Toffahy at optimum conditions (grading speed of $11 \mathrm{rpm}$ or $0.12 \mathrm{~m} / \mathrm{s}$ and feeding rate of $10 \mathrm{~kg}$ ).

Table 4: The components of Awady equation.

\begin{tabular}{|c|c|c|c|c|c|c|c|c|}
\hline $\begin{array}{c}\mathbf{p}, \\
\text { L.E. }\end{array}$ & $\mathbf{h , ~ h}$ & $\begin{array}{c}\text { a, } \\
\text { year }\end{array}$ & $\mathbf{i}$ & $\mathbf{t}$ & $\mathbf{r}$ & $\mathbf{E c}, \mathbf{k W . h} / \mathbf{h}$ & $\begin{array}{c}\text { Ep, } \\
\text { L.E. }\end{array}$ & $\begin{array}{c}\mathbf{m ,} \\
\text { L.E }\end{array}$ \\
\hline 2000 & 1500 & 10 & 0.075 & 0.05 & 0.03 & 0.4 & 0.25 & 1000 \\
\hline
\end{tabular}

$\mathrm{C}=2000 / 1500 *(0.1+0.035+0.05+0.06)+0.4 * 0.25+1000 / 144$

\section{CONCLUSION}

The main results in this study can be summarized as follows:

The maximum fruit damage of 6.7 and $6.4 \%$ Azzezy and Toffahy cultivars respectively, was obtained with grading speed of $8 \mathrm{rpm}(0.08$ $\mathrm{m} / \mathrm{s}$ ) and feeding rate of $20 \mathrm{~kg}$. the minimum fruit-damage of 3.1 and 3.3 $\%$, total 6.4 and $7.3 \%$ for Azzezy and Toffahy cultivars respectively, 20 $\mathrm{mm}$ fruit sizes was obtained with grading speed of $11 \mathrm{rpm}(0.12 \mathrm{~m} / \mathrm{s})$, and feeding rate of $5 \mathrm{~kg}$ The maximum range of grading-machine productivity for olive fruits of $113-836$ and $125-920 \mathrm{~kg} / \mathrm{h}$ for Azzezy and Toffahy cultivars respectively, was obtained with grading speed range of $5-14 \mathrm{rpm}(0.05-0.15 \mathrm{~m} / \mathrm{s})$ and feeding rate of $20 \mathrm{~kg}$. Meanwhile, the minimum range of grading-machine productivity for olive fruits of 101- 682 and $111-750 \mathrm{~kg} / \mathrm{h}$ for Azzezy and Toffahy cultivars was obtained with grading speed range of 5 - $14 \mathrm{rpm}(0.05-$ $0.15 \mathrm{~m} / \mathrm{s}$ ) and feeding rate of $5 \mathrm{~kg}$. Meanwhile, the minimum range of grading-machine productivity for olive fruits of $142.8-492.3 \mathrm{~kg} / \mathrm{h}$ was 
obtained with grading speed range of $5-14 \mathrm{rpm}(0.05-0.15 \mathrm{~m} / \mathrm{s})$ and feeding rate of $5 \mathrm{~kg}$. The operation and production costs were $7.37 \mathrm{~L} . \mathrm{E} . / \mathrm{h}$ and 67, 9.7 L.E./ton for Azzezy and 62.4 , 8.9 L.E./ton for Toffahy at optimum conditions (grading speed of $11 \mathrm{rpm}$ or $0.12 \mathrm{~m} / \mathrm{s}$ and feeding rate of $10 \mathrm{~kg}$ ).

\section{REFERENCES}

Abd-Alla, H. El. S. M. Radwan M. M. El-Kholy and M. S. Radwan (2000). A weight grading machine for fifferent fruits and vegetables. Misr. J. Agic. Eng., 17(3): 675-696.

Amin, E. E., 1994, Development of a grading machine for some horticulture farm crops, J.Agric. Sci. Mansoura Univ. 19(7) :31393149.

Awady, M. N., 1978, (updating 1998), Engineering of tractors and agricultural machinery. TextBook., Col. Ag., Ain-shams Univ., 5 th. Ed.,: 164-167. (In Arabic).

Buyanov, A. I. And Voronyuk, B. A., 1985, Physical and mechanical properties of plants, fertilizers and Soils, Amerind Pub. Co., PVT, LTD, New Delhi, Bombay, Calcutta, N. Y.: 15 - 97.

El-Raie, A. E., A. F. El-Sahrigi and M. Mosa (1998). Engineering factors affecting the development of graing machine for fruits. $6^{\text {th }}$ Conference of Misr Society of Ag. Eng., 21-22 Oct.: 79-90.

El-Raie, A. E., I.Yehia, , M. M. Attallah, and K. S. Khalil (2012). Factors affecting the design of a grading machine for lemon fruits, Misr J. Ag. Eng., 29(2): in Press. 
Fayed, M. and A. M. Attalla (1995). Physical and mechanical properties of fruits of some date palm cultivars growing in Gassim Region, Saudi Arabia. Misr. J. Agric. Eng., 12(3): 529-540.

Haydar H., I. Gezer, M. M. Ozcan And B. MuratAsma (2007). Post harvest chemical and physical-mechanical properties of some apricot varieties cultivated in Turkey. Journal of Food Engineering $79: 364-373$.

Huang, Y.; L. Shyushyang and Y. C. Chang (2000). The study on the physical property's indicesof grading for Indian Jujube. J. Agric. And Foresty 49 (4): 47-62.

Ismail, Z. E. (1988). Some of physio-mechanical properties for potato tubers.J. Agric. Sci. Mansoura Univ. 13(4): 2259-2270.

Matouk, A. M., A. M. El-Gengy, Y. M. El-Hadidi, E. A. Amin, and M. M. Abd El-Rahman (1999). Evaluation the effect of some mechanical parameters on handling characteristics of sphere-like crops. Misr J. Agric. Eng., 16(4):701-719.

Mohsenin, N. N., 1986, Physical properties of plant and animal materials, Gordon and Breach Sc. Pub., N. Y.:734.

Mousa, M. M., 1998, Engineering factors affecting the development of grading machine for citrus, Ph. D., Fac. of Ag., Cairo U.: 126-255.

Radwan, M.S.M. (2000). A weight grading machine for different fruit and vegetables. M.Sc. Thesis, Agric. Eng. Dept. Fac. Of Agric.,. Mansoura Univ.

Shabana, M.M.E. (2002). Manufacture and evaluation of a small machine for grading orange fruits. M.Sc. Thesis, Agric. Eng. Dept. Fac. Of Agric.,. Tanta Univ. 


\section{الملخص العربى \\ تطوير آلة لتدريج ثمار الزيتون \\ د. ميرفت محمد عطالله(*)}

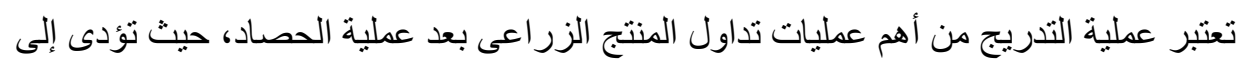
رفع جودة المنتج النهائى سواء للأستهلاك المحلى أو التصدير. بسم الله الرحمن الرحيم (و التين و الزيتون وطور سينين* وهذا البلد الأمين* لقد خلقنا الإنسان في أحسن تقويم) يمثل الزينون واحدا من المحاصيل الهامة التي تقوم علي أساس صناعات أخري، كما انه من المكن زر اعنها في الأر اضي الجديدة و الصحر اوية.

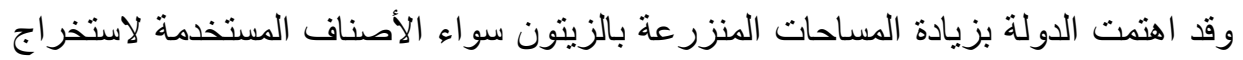

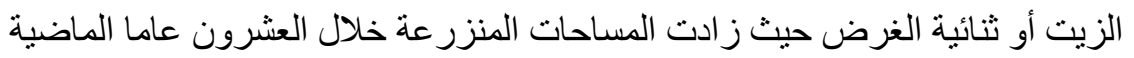

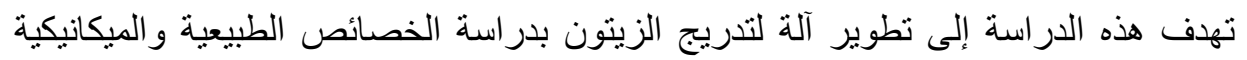

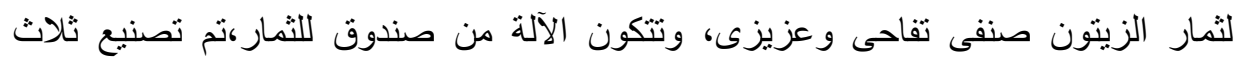

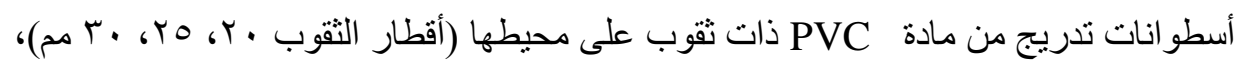

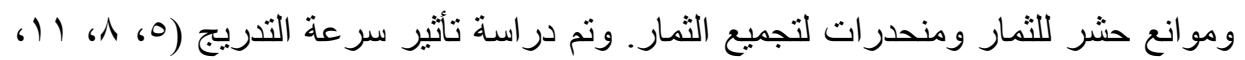

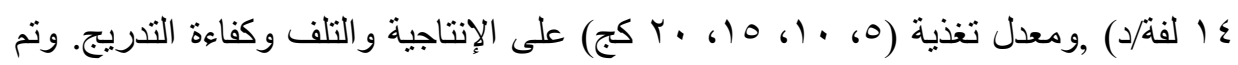
الحصول على النتائج التالية:

(1) تأثير سرعة أسطوانات التدريجج وكمية الثمار على كفاعة التدريجِ: تأثيرِ السرعةِ وكميةِ الفاكهةِ على كفاءة تتدريج الثمار لأربعة حجوحِ للثمارِ

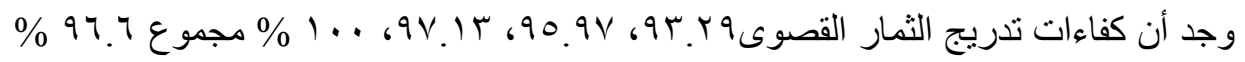

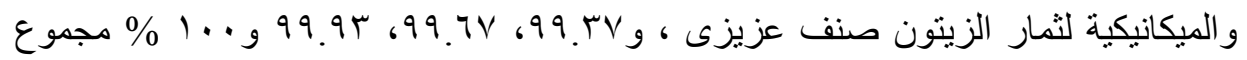

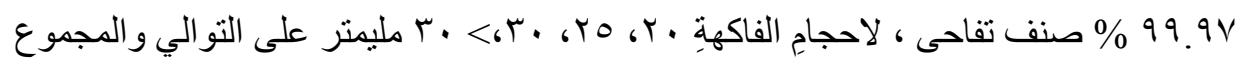

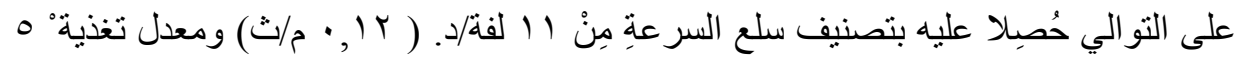

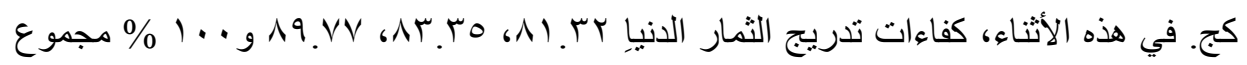

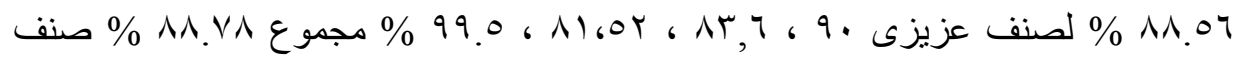

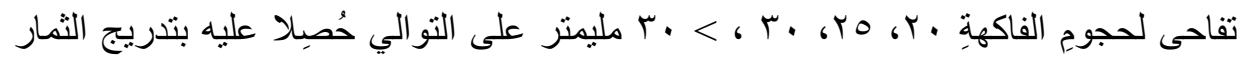

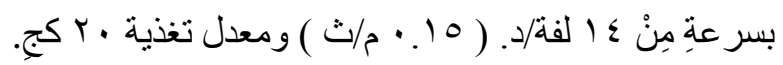

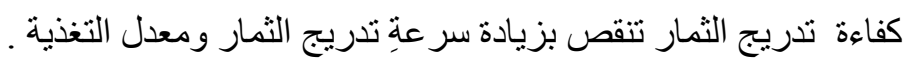

(*) باحث بمعهل بحوث الهندسة الزراعية. 
(Y) تأثير سرعة أسطو انات التدريج وكمية الثمار على التلف: وجد أن أقصى ضرر للفاكهةٍ

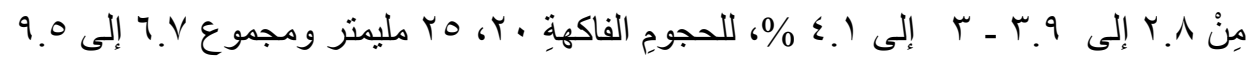

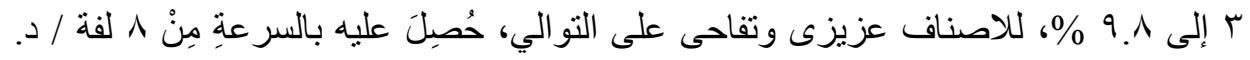

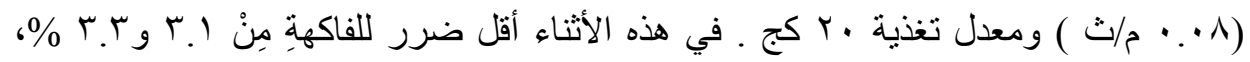

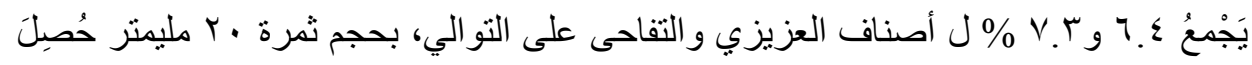

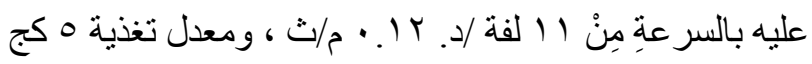

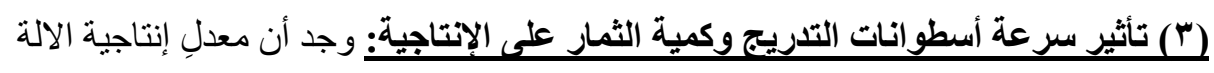

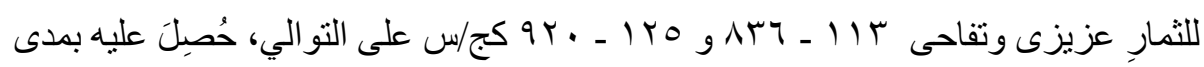

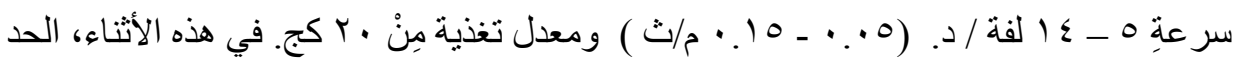

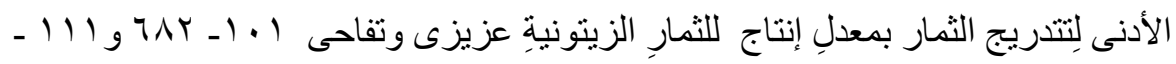

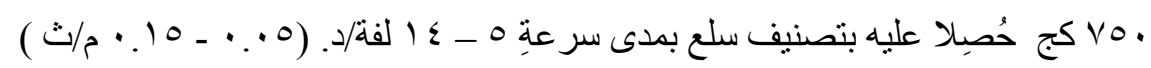
ومعدل تغذية 0 كج.

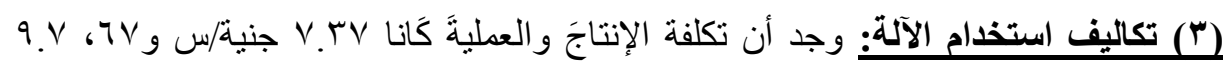

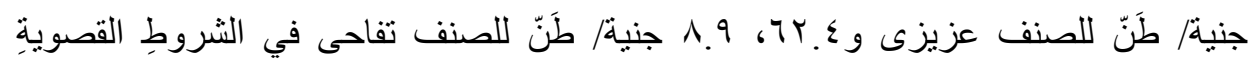

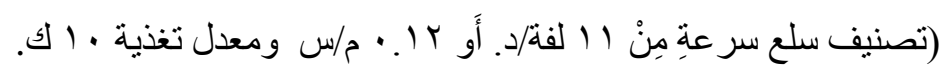

